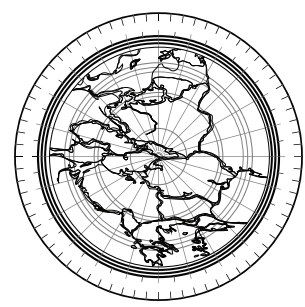

Sprawy Narodowościowe: Seria nowa, 2021(53), Article 2546

\title{
Defending the Traditional Polish Way of Life: The Role of Fantasies
}

DOI: https://doi.org/10.11649/sn.2546

\author{
Francesco Melito \\ Jagiellonian University, Kraków \\ https://orcid.org/0000-0002-9323-0328 \\ e-mail: francesco.melito@uj.edu.pl
}

\begin{abstract}
The current escalation of the cultural conflict in Poland is described as a cultural war between neo-traditionalist and liberal worldviews. Drawing on psychoanalytic political theory and Poststructuralist Discourse Theory (PDT), fantasmatic narratives are deemed as an instrument to conceal the non-necessary character of identities. Based on the direct observation of the counter-marches against LGBT parades in Kalisz, Lublin, and Kraków (2019-2020), this article shows how fantasies define the 'authentic Polish way of life': from the traditional family in an idyllic scenario (beatific fantasy) to the 'LGBT virus' (horrific fantasy), fantasies sustain a neo-traditionalist conception of Polishness and exclude antagonistic visions. Also, religious symbols are sublimated to embody the lost unity: a harmonious society without the conflict generated by the liberal value system. The fantasmatic logic analyzed in the article explains how neo-traditionalist fantasies strengthen identities and provide the necessary ideological ground to resist the emancipatory impetus of liberalism.
\end{abstract}

Keywords: neo-traditionalism; poststructuralist discourse theory; fantasy; logics approach; Polishness

This research is part of a project that has received funding from the European Union's Horizon 2020 research and innovation programme under grant agreement no. 765224 .

No competing interests have been declared.

Publisher: Institute of Slavic Studies, Polish Academy of Sciences.

This is an Open Access article distributed under the terms of the Creative Commons Attribution 3.0 PL License (creativecommons.org/licenses/by/3.0/pl/), which permits redistribution, commercial and non-commercial, provided that the article is properly cited. (c) The Author 2021. 


\section{Introduction}

In the beginning, it was about refugees. The current radicalization of the Polish political debate over 'cultural' issues can be traced back to the parliamentary electoral campaign in 2015, which focused on the question of multiculturalism and the relocation of refugees. In 2016 another ethical issue contributed to further dividing Polish society: the right to abortion. In October 2020, following a decision taken by the Constitutional Court to restrict access to abortion, this clash re-emerged: thousands of people took to the streets of several Polish cities and towns to protest against the court ruling. Protesters targeted religious places as symbols of the Catholic moral influence over the country; as a response, nationalist and religious groups stood in front of the churches to protect them, while Jarosław Kaczyński (the leader of the ruling Law and Justice party) called on people to defend Poland and the Catholic Church. The cultural war has also touched upon the field of civil rights. The confrontation between LGBT activists and the 'defenders' of the traditional family became harsher as parliamentary and presidential elections were held respectively in 2019 and 2020.

These emblematic events show the main lines of conflict of what can be defined as the Polish Kulturkampf (Grabowska, 2020). Indeed, they cannot be considered episodic and unrelated. They are the tip of an iceberg that has its base hidden in a deeper cleavage between two different worldviews. A liberal Weltanschauung, Western imported, which regards the individual and their free will as the highest value, on the one hand. A neo-traditionalist reaction that seeks a common and traditional morality beyond axiological individualism, on the other hand (Korolczuk \& Graff, 2018; Trencsényi, 2014). ${ }^{1}$ The former, embedded in the European Union and its values, has become hegemonic during the transition (Biegoń, 2016). The latter can be considered one of several non-liberal counter-revolutions that, according to Jan Zielonka (2018), are taking place in Europe and reject the post-1989 liberal order. ${ }^{2}$

These events can be ascribed to the so-called 'illiberal turn' (or 'swerve', as referred to by Bustikova \& Guasti, 2017) that is taking place in Central-Eastern Europe. Often also described as populist, ${ }^{3}$ the illiberal turn signals the progressive erosion of liberal democratic values in the region in favor of an illiberal conception of democracy (Orbán, 2014). This political development has received significant attention from several observers. In the case of Poland, some scholars have looked at the rise of illiberalism from a strategic perspective.

1 Talking of two monolithic worldviews in Poland would be naïve and would deny our ontological assumption of non-given identities; this division, indeed, does not imply an essentialist core of the neo-traditionalist or the liberal discourse. Rather, it seeks to offer an introductory snapshot of the current situation in Poland.

2 More precisely, Zielonka (2018) suggests that, in contemporary Europe, illiberalism relates to all those counter-revolutionary political actors that refuse liberalism. While they are similar in terms of what they are not like (they are not liberal), their positive defining characteristics might be very different. In this article, we will discuss neo-traditionalism as one of these illiberal discourses.

3 We prefer not to use the adjective 'populist' since its definition is controversial and would switch our focus to different matters. 
These works focus, for instance, on emotional stratagems (Cap, 2018), the strategic politicization of a single issue (Krzyżanowski, 2018), or a paranoid political style (Sadurski, 2018) as political mechanisms to secure support. Another significant theme concerns the performative construction of 'the other' (Yatsyk, 2020) as well as the use of symbols to legitimize illiberal discourses (Kotwas \& Kubik, 2019). The performative aspect has relevance also in this article. As discussed below, symbols and the projection of a 'thief' play a fundamental role in the narration of neo-traditionalist fantasies. However, we find fantasies as an ingredient of the neo-traditionalist discourse, rather than as a strategic appeal to emotions.

This article differs from the 'strategic perspective' analysis of illiberalism. Instead, it positions itself within that body of literature that investigates the ideational content of illiberalism in Central-Eastern Europe, which has attracted little attention thus far (Buzogány \& Varga, 2018). Despite internal differences, it is possible to glimpse a pattern within the illiberal camp in Poland, which, more or less consciously, is seeking to rebuild a non-liberal common sense. This alliance that combines nationalist (or, for some, populist) stances with religious sentiments and traditionalist values has been described as a neo-traditionalist counter-hegemonic discourse (Melito, 2021), an illiberal populist ideology (Korolczuk \& Graff, 2018), a counter-elite populism (Bill, 2020), or a conservative discourse coalition (Dąbrowska, 2019). These approaches, different in some aspects, identify the existence of an ideological project with certain characteristics. Notwithstanding their different terminology, they all describe a political or discursive alliance opposing what they perceive as the dominant cultural values of liberalism.

In this work, this ideological project is defined as a neo-traditionalist discourse: by referring to the work of Ernesto Laclau and Chantal Mouffe (Laclau \& Mouffe, 1985), this definition indicates a discursive construction that links in a chain of equivalence traditionalist demands and the antagonistic division of the social into a neo-traditionalist and a liberal camp. At the center of this clash, there is the 'way of life' Poland should adopt. There is 'Polishness' (polskość) as the key value that defines Polish identity. However, the very meaning of 'Polishness' is far from clear. The argument posed by Wojciech Chlebda (2017, p. 8), according to whom "this clash has led to the enantiosemy of the Polish communication space, which caused that one and the same signs are able to express opposing contents, values and emotions", suggests that 'Polishness' has become what Laclau (2005b, p. 43) describes as "floating signifier": its meaning varies depending on its articulation with other discursive elements and might take on different forms in different contexts.

Drawing on Poststructuralist Discourse Theory (PDT) and its ontological premises, this article will look into those neo-traditionalist fantasies that conceal the floating meaning of 'Polishness'. According to PDT, no identity can be fully attained as it will always be subjected to a process of re-signification (Glynos \& Howarth, 2007). As 'our way of life' is an elusive entity, fantasies make "visible the unique way a community organizes its enjoyment" (Žižek, 1993, p. 201; emphasis as in the original). The goal of the article is to understand and explain how neo-traditionalist fantasies cover over the non-necessary and mutable nature of 'Polishness' and exclude alternatives. This ideological construction of fantasies justifies the ongoing 
mobilization and resistance in Poland against the inexorable advance of the post-materialist revolution (Ignazi, 1992). In other words, fantasies are necessary to conceal the fact that what we believe to be 'our way of life' might not necessarily be so. They hide the fact that Polishness might also include multiculturalism or alternative models of family, ${ }^{4}$ and defend traditions against modernity. This fantasmatic dimension is a crucial aspect of the neo-traditionalist attempt to hegemonize Polish common sense and define normality. Neo-traditionalist fantasies are an important weapon in the Polish cultural war as they provide the affective energy to resist the changes brought about by liberal values and modernity.

An example of this neo-traditionalist fantasmatic narrative is offered by counter-marches that have been organized by nationalist and religious organizations and individuals to oppose LGBT parades. On these occasions, neo-traditionalist groups have followed and attempted to block the parades, displaying their symbols and defending their idea of Polishness. The empirical analysis will focus on these illustrative events and will use PDT as a lens for the explanation of the neo-traditionalist fantasmatic logic: on the one hand, LGBT parades function as a dislocatory experience for the concept of (neo-traditionalist) Polishness, showing its contingent character; on the other hand, traditionalist symbols embody the fantasy necessary to conceal and positivize the traumatic encounter with dislocation. ${ }^{5}$ As claimed above, the debate about civil rights is just one of the clashes of the cultural war in Poland. Yet, the large use of traditional symbols opposed to LGBT signs suggests that the ideational battle goes beyond the peculiar dispute about civil rights. The counter-marches are just an expression of a wider neo-traditionalist discourse that perceives LGBT demands as a threat to their Polish way of life.

\section{A Neo-Traditionalist Discourse in Poland}

Has the lot of the Poles up to now been so delightful? Has not your Polishness become loathsome to you? [...] To the Devil with Pater and Patria! The Son, the son's the thing, oh, indeed! But wherefore need you Patria? Is not Filistria better? You exchange Patria for Filistria and then you'll see!

Witold Gombrowicz (1994, p. 57), Trans-Atlantyk

The clash between different worldviews in Poland can also be read as a clash between modernity and tradition. The former goes hand in hand with liberalism as they both aim at removing the obligations of the past and promise negative freedom to individuals. The modern and liberal individual seeks to get rid of heteronomous systems of values and become

\footnotetext{
4 It needs to be stressed that there also exist opposite fantasies with a similar function. 'Liberal fantasies', however, are out of the scope of this article.

5 According to Laclau (1990), dislocations have a twofold character: they are both a threat to identities (negative) and the terrain where new identities are founded (positive).
} 
"the locus of moral judgment and choice" and "the final adjudicator of morality" (Carse, 1994, p. 186). Conversely, traditions serve as points of reference in people's life when modernity and progress break with the past (Burke, 2003). Traditional values furnish a mental map to understand the world and to find again the lost direction sacrificed on the altar of freedom. Hence, individual liberty is incompatible with tradition and its prescriptive nature. Traditionalism was considered by Edward Shils (1958) as a reaction against modernity. Whereas liberal modernity liberates people from the chains of prejudice, traditionalism provides stable and permanent values that find their legitimacy as stemming from the past.

The term neo-traditionalism has been borrowed from anthropology and post-colonial studies: it indicates the rejection of foreign cultural influence and the construction of a new (old) identity that refers to traditions (Friedman, 1994; Rata, 2007). ${ }^{6}$ In the context of former colonies, neo-traditionalism has been used as a political strategy that legitimizes tribal elites and rejects the cultural influence of Western powers. The rejection of the colonizers entails the rejection of their modernity. ${ }^{7}$ References to the past serve to re-establish a culturally defined identity opposed to the Western one and constructed upon a 'more genuine way of life'. Accordingly, "neo-traditionalism is a view that rejects modernism and seeks an organic form of existence. [...] It aspires to return to the importance of values and community that presumably existed before modernist rationality drove out customary verities" (Fisher, 2005, p. 242). Thus, like traditionalism, neo-traditionalism refuses modernity and individualism, and it praises stable values and the importance of the community. However, the prefix neo- indicates a political strategy "deployed in different ways by both elites and ordinary people" (Galvan, 2007, p. 599) that reproduces past cultural patterns to legitimize itself. Not only is neo-traditionalism against modernity; it also associates modernity with a foreign and extraneous influence. Not only does neo-traditionalism claim to return to tradition; it also presents a political dimension to achieve this goal. Yet, it is necessary to explain how an anthropological concept used in the context of former colonies can be applied also in political analysis in Europe.

As aptly noted by Elżbieta Korolczuk and Agnieszka Graff (2018), illiberal actors in Central-Eastern Europe have increasingly deployed an anti-colonialist narrative. Cosmopolitan elites from the West are accused of imposing alien liberal values and globalizing processes on post-socialist countries. As in former colonies, this discourse has a neo-traditionalist component as it refers to an authentic original culture that is threatened by the corrupt West. It is the liberal West that is considered foreign as it tries to replace the old traditions of the past. Neo-traditionalism in Central-Eastern Europe is, therefore, a revolt against Western modernity and liberal values (Benczes, Kollai, Mach \& Vigvári, 2020). At the same time, a neo-traditionalist

6 The post-colonial approach applied in this article makes a different use of the concept of neo-traditionalism than in sociology, where it has been employed to describe the mixture of modern and traditional elements in communist countries (Jowitt, 1983; Walder, 1986).

7 It needs to be stressed that in this case modernity does not necessarily refer to industrialization or the use of technology. While tradition refers to a world with stable, culturally defined values, modernity "is defined from this [traditionalist] perspective as a universe emptied of meaning, peopled by alienated individuals" (Friedman, 1988, p. 449). 
discourse has a positive content as it shapes new identities: neo-traditionalism (negatively) accuses the liberal elite of disrupting the 'authentic culture' and (positively) reproduces elements of a past culture to cope with a loss of ontological security. In Central-Eastern Europe, the defining features of neo-traditionalism refer mainly to the ethnic-national community, traditional social roles, and the sovereignty of the people (Kubik, 2018). ${ }^{8}$

What does this discussion tell us regarding the floating meaning of Polishness? Oftentimes, Poland is described as internally split into two parts: liberal and conservative, West and East, cities and rural areas. This basic and descriptive distinction, yet commonly and historically accepted, provides a first hint regarding the signification of the signifier Polishness. ${ }^{9}$ As advocated by Gombrowicz (1994) in Trans-Atlantyk, Polishness need not refer to the Fatherland and respect for authorities. A new Polishness emerges in his novel, devoid of the old bonds to the Polish community and emphasizing the liberty of the individual. He named it using the evocative neologism Filistria (synczyzna). Killing the Father is a metaphor that illustrates the desire for overcoming the burden of tradition. The aspiration of the Son is the aspiration of modernity and the current liberal discourses. Conversely, what we can call neo-traditionalist Polishness reflects the discussion between modernity and tradition. Rather than breaking the superstructural chains, neo-traditionalism emphasizes the obligations created by the ethno-national community and religion. In this case, 'Polishness' comes to be signified in a neo-traditionalist way by articulating traditionalist demands: it refers to an ethno-nationalist identity and to the Christian roots of Poland. It protects traditional models of community and communitarian morality. It privileges authority and hierarchy over individual liberty, and stability over relativism. In other words, it is connected to the allegedly genuine and authentic Polish way of life, linked to the safe environment of traditions. Liberal modernity, instead, is seen as a foreign agent that is trying 'to steal' this way of life.

The different possibilities to construct Polish identity make clear their contingent character - when the traditionalist idea of Poland is questioned, the entire house of cards may collapse showing its radical contingency. Fantasies play a crucial role in hiding this uncertainty. By constructing fantasmatic narratives, subjects are attached to a certain identity, making it more difficult to put it into question. The affective investment in fantasies and symbols helps subjects sustain a certain idea of 'Polishness' (traditionalist, liberal, or, potentially, any other): "In this (Lacanian) perspective fantasy serves to protect the subject (of desire) from the anxiety linked to a direct confrontation with the radical contingency of social relations" (Glynos, 2008, p. 286).

8 In this respect, it should be noted that neo-traditionalism is partially different from conservativism. The latter is a full-fledged ideology seeking to cover each aspect of society (Dąbrowska, 2019); the former, instead, is interested in rejecting modern and post-modern values and reproducing a worldview that is an alternative to the worldview of liberalism and that can tell its adherents their position in the world and their direction.

9 This distinction is not to be considered essentialist. See note 1. 


\section{The Fantasmatic Logic}

The term fantasy belongs to the psychoanalytic tradition. As explained by Yannis Stavrakakis (1999), Jacques Lacan used the concept of fantasy to indicate an imaginary construction that promises to cover the traumatic entrance of the baby into language and culture (the symbolic order). Traumatic to the extent that the baby suffered a theft of a pre-symbolic full enjoyment (jouissance), which was satisfied by living in symbiosis with the mother (Zicman de Barros, 2020). This symbolic castration generates a fault within the subject, who, since this moment, will desire to regain this lost unity (Sharpe \& Turner, 2020). The search for this inaccessible wholeness (which Lacan calls the Real) motivates our desire and can be covered only by a fantasy, namely the promise of gaining back that idyllic condition: "it is exactly this impossibility that forces us to identify again and again. We never get what we were promised but that's exactly why we keep longing for it" (Stavrakakis, 1999, p. 34).

Inspired by psychoanalysis, Slavoj Žižek (1989) has adapted the concept of fantasy to political theory and, since then, Lacan's work has acquired increasing importance in the theoretical development of discourse theory. In psychoanalytic political theory, the ontology of psychoanalysis is transferred to fantasmatic narratives: the same traumatic loss of unity experienced by the subject is present in society, which is antagonistic and conflictual rather than harmonious and consensual (Žižek, 1989). In a similar manner as in Lacan, ideological fantasies aim to cover the inherent lack in society with the promise of a fullness-to-come; the overcoming (by covering over) of conflicts and antagonism (Homer, 2020). As noted by Matthew Sharpe and Kirk Turner,

fundamental fantasies, for Lacan and Freud, re-narrate the origins of the individual, positioning them as the more or less passive victims of a theft of enjoyment by the Other. Just so, ideological fantasies will position the sublime Thing - national unity or greatness, the dictatorship of the proletariat, the community of the people, and so on - as having been stolen, damaged or corrupted, always by some contingent, external force. (Sharpe \& Turner, 2020, p. 195)

The functioning of ideological (or fundamental) fantasies is clear in nationalist narratives: the Thing that bonds the members of the community is 'our way of life'. This way of life (which is not further specified) can be visible through a series of signifiers (embedded not only in texts but also, and especially, in rituals, myths, and symbols) that point to the lost unity and make visible how a community organizes its enjoyment (Žižek, 1993). While 'our way of life' is elevated to stand for the lost enjoyment, a nationalist narrative also blames external enemies for stealing the national Thing. On the one hand, the enemy wants to ruin 'our way of life'; on the other hand, their perverse way of enjoyment ('their way of life') represents a threat to the survival of the national community (Žižek, 1993). 
The logics approach developed by Jason Glynos and David Howarth (2007), and in particular the fantasmatic logic, provides methodological clarity to this scheme. As discussed in the previous part, 'Polishness' can be considered a floating signifier whose open meaning and identity depend on its articulation with other discursive elements in a chain of equivalence. If all identities are contingent and depend on their articulation, how can they survive the constant crises and attacks brought about by dislocatory experiences? How can traditionalist Polishness resist modernity? In her analysis of Israeli identity, Jacqueline Rose asks as follows:

What would happen to a political or religious identity, even the most binding, if it could see itself as contingent, as something that might have taken another path? Can you be devoted to an identity - or would you be differently devoted to an identity - if you knew it was also unsure? (Rose, 2005, p. 96)

Hiding the non-necessary character of the social, fantasies are fundamental in the protection of any identity through their affective force. In this regard, the fantasmatic logic explicates why a certain narrative is able to offer an ideological grip to subjects. "Fantasy operates so as to conceal or 'close off' the radical contingency of social relations" (Glynos \& Howarth, 2008, p. 12). At the analytical level, three categories can be identified. The beatific fantasy, the horrific fantasy, and the fundamental fantasy. Beatific and horrific dimensions of fantasies are indicated by Glynos and Howarth (2007) as the two main forms of deploying an affective and ideological investment. The former is associated with a utopian future, a golden age, or a sense of omnipotence. Looking for a beatific fantasy in a discourse involves the search for those imaginary elements that point to a bright future, to opportunities (Remling, 2018) as well as to the removal of and the defense from the enemy. Horrific fantasies refer to a dystopian future where the enemy has stolen 'our enjoyment'. It is associated with the imaginary construction of the Other as 'stealing', 'taking away' something, or with expressions predicting an imminent disaster and the destruction of our community or a symbol of it. Similarly, as already mentioned, it is also their perverse way of enjoying disturbing 'our way of life' (Žižek, 1993). From this discussion, we can argue that fantasies serve to strengthen a political project that seeks to hegemonize common sense: beatific fantasies narrate the return to a lost unity, as symbolized by a utopian future without antagonism. Horrific fantasies, in turn, defend a certain identity from dislocatory experiences. Beatific and horrific fantasies, therefore, describe the affective power that holds subjects tied to a certain identity by referring to a lost totality or a fullness-to-come (Hawkins, 2015). Yet, they do not explain what this imaginary totality is and nor do they specify how to define it analytically.

As pertaining to the Real, this lost unity is lost forever. The only mechanism to access this enjoyment is through sublimation: partial objects are elevated to the dignity of the lost Thing (Laclau, 2005a). It is important to underline that this is not a relation of representation; rather, objects are sublimated and thus their value is not second best compared to the lost 
enjoyment (Biglieri \& Perelló, 2020). For example, the national flag is not only a symbol of the nation; rather, it stands physically for the nation to the point that a soldier would die to defend it. Sublimation has serious implications for the empirical analysis presented in this article: as a sublimation of the Thing, the fundamental fantasy lends itself to being assumed by symbols (e.g. flags) or rituals (e.g. national parades) that exemplify 'our way of life'. They represent at the same time the lost totality that feeds subjects' desire and the fantasy that conceals this lack.

\section{Marching Fantasies: The Anti-LGBT Case}

Since 2001, Marsze Równości (Marches of Equality, LGBT parades) have taken place in many cities around Poland and, at the same time, they have generated severe counter-reactions. Most of the LGBT parades are literally followed by counter-demonstrators, who express their dissent in various ways. In the most notable case, in July 2019, in Białystok, counter-demonstrators (largely members of far-right groups and football hooligans) violently attacked the local LGBT march causing a stir in the country. The violent clashes in Białystok have radicalized the confrontation between LGBT activists and their opponents in Poland. Although following these events LGBT parades are even more heavily protected by the police, counter-marches and clashes have not stopped.

This analysis of neo-traditionalist fantasies has been conducted through the direct observation of counter-marches against LGBT parades. The demonstrations attended by the author took place in Kalisz, Lublin (22 and 28 September 2019, right before the parliamentary elections held in October), and Kraków (29 August 2020, a few weeks after the presidential elections in June and July). The distinct locations of the marches provided different perspectives: while Kalisz is a relatively small city in western Poland, Lublin is a regional capital and one of the most important cities in the east of the country. ${ }^{10}$ As a consequence, the rather small and calm counter-march in Kalisz ( $a$ few hundred people) was not as turbulent as the one in Lublin (a few thousand), where police charged the counter-demonstrators and arrested some of them. Unlike in Kraków, both in Kalisz and Lublin the counter-marches were attended by different groups: not only hooligans and far-right organizations but also 'ordinary people' who did not show any political affiliation. Owing to the absence of 'ordinary' counter-demonstrators and the liberal and international orientation of the city (the second largest in Poland, capital of a region), the LGBT parade in Kraków was the only one that clearly outnumbered the counter-march (in Kalisz and Lublin counter-demonstrators were probably more numerous). It has to be said, though, that both marches in Kraków were rather small (probably because of Covid-19 restrictions,

10 It is important to note that eastern Poland is considered to be a bastion of traditionalism and conservativism, while western Poland is known as more liberal. 
only a few dozen people took part in the counter-march, although Kraków is much larger than both Kalisz and Lublin); yet, the counter-march provided several insights because its limited route around the main square made the observation easier.

In terms of analysis, all discursive productions were taken into consideration: banners, body language, physical acts, symbolic objects, chants, slogans, speeches (in line with PDT, both linguistic and non-linguistic data constitute text). The data gathered are to be understood as elements of the neo-traditionalist discourse and as fantasmatic narratives that protect 'traditionalist Polishness'. Except for an interview with an anonymous politician during the counter-march in Lublin, the author did not disclose their identity and acted as one of the many silent observers of the counter-marches. In a few cases the author walked with LGBT activists in order to have a more complete picture; this was possible only in Kraków and Kalisz, as in Lublin the police kept the two marches separated.

The three fantasmatic dimensions explain how counter-demonstrators are affectively attached to their standpoint and contrast the opposite worldview. These fantasies are described as neo-traditionalist since they picture an external enemy that, just like a colonial power, is trying to impose its foreign values (horrific fantasy). At the same time, the fantasmatic stories emphasize traditionalist elements, such as the national community, religion, traditional social roles, and permanent values (beatific fantasy). Finally, as in post-colonial neo-traditionalism, they refer to an authentic way of life, which is sublimated in partial objects (fundamental fantasy). All three fantasmatic dimensions were visible in the counter-marches and they explain why the cultural war in Poland is still raging.

In the selected field of analysis, the threat to 'our way of life' is represented by LGBT parades. The very act of marching with rainbow banners and rainbow symbols is seen as a danger for the idea of traditionalist Polishness. Hence, counter-demonstrators march next to LGBT parades to protect their world. In their narrative, the latter risks disappearing if LGBT activists achieve their goal. This horrific scenario, the dystopian future that will happen if the LGBT value system wins, portrays the disruption caused by the enemy and its 'perverse way of enjoyment'. For instance, a flyer distributed at the counter-march in Lublin warned:

Warning, rainbow plague! [...] This ideology aims to change the way of thinking, valuing and to create a different family, with the exclusion from the social life of those who do not agree, to the point of legal stigmatization.

The consequences foretold by this horrific fantasy entail the dislocation of traditionalist Polishness. The LGBT attempt to resignify the main tenets of the 'genuine' Polish way of life is considered to be a threat coming from the outside; LGBT organizations, as well as the European Union, are described as trying to impose another set of values, one that aims to change what is normality. ${ }^{11}$ This form of perceived colonialism is rejected in the name of an authentic Polish ethnic community. Indeed, the LGBT community and the EU are

11 Interview conducted by the author with an anonymous politician participating in the counter-march in Lublin. 
pictured as foreign agents operating in Poland. The text of a chant sung by participants of the counter-march in Kraków was as follows: "Here it's Poland, not Brussels - here there is no support for perversion".

This dislocatory experience depicting an external element inside the pure community was performed in a spectacular way in the counter-marches in Kalisz and Lublin: wearing white lab coats, members of the far-right organization All-Polish Youth (Młodzież Wszechpolska, MW) followed the Marsz Równości along the entire route cleaning, sweeping, and disinfecting after the 'LGBT virus.'. ${ }^{12}$ Spectacularizing their rejection of a different Poland, the message is clear: their concept of Poland cannot be infiltrated by something alien, embodied in this case by a virus. The LGBT virus is displayed as an agent that wants to break down the existing structure and the existing values of the country. This fantasmatic narrative foretells an imminent disaster if the external agent is not removed from the body. As in a typical exclusionary narrative, what is at stake is the very idea of 'our way of life'. The performance of the disinfecting squad is just necessary to conceal the very fact that 'their way of life' may change society; that another Poland (and another Polishness) is marching ahead of them. As described in the theoretical framework, the lost unity, the harmonious society without antagonism, is posited as a lost jouissance: the enemy is responsible for this loss and is accused of the 'theft of enjoyment':

We stress our affection for those values they fear so much; they spit on; those values they want to deprive the Polish nation of. But we will surely guard them and raise the next generations in this spirit. [...] The ideological war continues. (participant in the counter-march in Kraków)

These examples show how fantasies are necessary to prevent foreign values from affecting traditional Polishness. By calling to arms against the foreign enemy, fantasies provide the ideological force needed to resist the alternative discourse. As in a (virtual) leaflet published on a social network inviting people to participate in the counter-march in Lublin: the leaflet urges people to say no to homosexuality and the Western way of thinking; to defend the true idea of Poland. What is at risk is the utopian idea of Poland, represented by the 'traditional family' (a man, a woman, two children, and a dog) drawn at the top of the leaflet in an idyllic sunny scenario.

Indeed, horrific fantasies are not enough. We know from PDT (Glynos \& Howarth, 2007) that a fantasmatic narrative includes a beatific dimension: a promise that if an obstacle is overcome there is a bright future ahead. This beatific fantasy is displayed in the flyer as an original form of enjoyment (the unity of the family). The caption announces: "For hundred years Polish family has looked exactly like that"; and further: "Say yes to Poland so that Poland can be Poland". Two considerations can be pointed out here: first, the traditional family and the national community are articulated as equivalent. This articulation shapes

12 Note that both marches took place before the Covid pandemic and there is no reference to it. 
the neo-traditionalist character of the counter-marches. The reference to the past signals the authentic traditional way of life that is allegedly better than modern models; it also claims its superiority owing to its origin in the past. Second, this equivalence defines the concept of Poland. 'Poland can be Poland' only if it includes the fantasy of an idyllic family. It does not even matter whether the idyllic family represents the current Polish way of life or just a utopian projection. The beatific fantasy conceals the fact that alternative families may exist in Poland (as evident from the demands of the LGBT people marching next to them). The presence of Polish LGBT activists right there is neutralized by excluding them from their idea of Poland; in this regard, they are treated as foreign colonizers.

The same beatific fantasy is present in the stylized illustration of the traditional family featuring on several banners in all the counter-marches. The traditional family is always pictured as being under the threat of the LGBT storm. Also in this case, the traditional family, whose very existence is in danger, is narrated as a beatific fantasy. To stress the link between family and nation, the family is often protected by a red and white umbrella that resembles the Polish flag. Moreover, this bond was emphasized in the slogan "Family is the strength of the nation" (Rodzina siła narodu), which signifies and highlights the equivalential links between the discursive elements 'family' and 'nation'.

These horrific (e.g. Poland deprived of her values) and beatific fantasies (e.g. the call for a Great Catholic Poland, Wielka Polska Katolicka) try to conceal the liberal attempt of resignifying Polishness. In both cases, fantasies seek to defend the lost Thing, that sense of unity that precedes the dislocatory experience. This incommunicable unity, the access to enjoyment, can only be achieved by elevating objects to a higher level. We have described this mechanism as sublimation.

According to Laclau (2005a), a sublimated object goes beyond mere representation. In sublimation, we are not dealing just with a partial symbol of a lost totality; rather, the sublimated object stands as the actual lost totality. If a beatific fantasy promises a utopian future, the sublimated object is what makes that future so bright; the radical investment in this object means that the object itself becomes "the embodiment of a mythical fullness" (Laclau, 2005a, p. 115). This analysis argues that the sublimation of partial objects was observable in the counter-marches; in particular, the Christian cross and the rosary assumed a special role. The use of these objects has two implications. First, they add another layer to the characterization of 'neo-traditionalist Polishness'. The chain of equivalence between nation-family-traditional values that has been described above comes to include also a religious aspect: 'neo-traditionalist Polishness' is also defined by Christianity. As discussed by Brian Porter-Szúcs (2017), the term 'Pole-Catholic' (Polak-katolik) appears with more frequency when this tie is in danger. By calling for secularism, LGBT marches put into question the idea that the Polish nation needs to be inherently Catholic. They put into question the unity of Poland. This threat leads to strengthening the tie between Poland and Catholicism to the extent that religious objects come to embody the Nation as well as 'our truthful way of life'. The Pole-Catholic knot reinforces the idea of a community without antagonism. 
The second implication deals with the affective importance of the cross and the rosary. These two objects were used in the three marches as if they were shields against the LGBT parades. As the Marsz Równości advanced, counter-demonstrators displayed their rosaries, crosses, and religious pictures to protect themselves and, figuratively, to protect their idea of Catholic Poland. At that moment, these sublimated objects embody the very idea of the Nation; they are the incarnation of the original enjoyment. By raising their crosses and rosaries, the counterdemonstrators show how their way of life clashes with the opposite one. On one side there are dances, pop music, glitter, colorful and fancy clothes, and rainbow flags; in other words, a cultural model based on individual liberty and a form of enjoyment that emphasizes the freedom of the individual to break the bonds imposed by tradition. On the other side - religious symbols, prayers, national flags, and patriotic chants are displayed; the rosary is used as a powerful object, something more than just beads. ${ }^{13}$ They all are objects and rituals that embody 'our way of life'. Opposed to individual liberty, they stress a form of enjoyment linked to communitarian freedom. From this point of view, there is no freedom outside the rules of the community. The affective investment in these objects, this fundamental fantasy, covers and protects the members of the community from the disruptive resignification of a different Polishness.

\section{Conclusion}

A common liberal argument in Poland concerns the backwardness of those who refuse modern values. The so-called ciemnogród, the obscurantism of that part of Poland that is still bound to old traditions, is often seen as an obstacle to catching up with the modern West. While the rest of European countries have gradually accepted post-material social values (Rensmann, 2017), traditionalist worldviews still resist in Poland (and, arguably, in most of the former communist countries). This attachment to traditional values is considered to be an anomaly in the secularized Europe. The analysis provided in this article has sought to explain the underlying narratives that make this resistance still so powerful; it has sought to show the ideological background sustaining this non-liberal counter-revolution.

In terms of the psychoanalytic theoretical framework applied in this empirical analysis, fantasies 'defend' traditionalist Polishness from its liberal resignification. In fact, apart from their symbolic valence, LGBT parades pursue political goals that counter-demonstrators view as unacceptable. The role of fantasies "is to actively contain or suppress the political dimension of a practice" (Glynos \& Howarth, 2007, p. 146). Hence, we can read fantasmatic narratives as ideological weapons to oppose the attempted redefinition of Polish identity. Neo-traditionalist fantasies offer a solid ideological ground for defending and strengthening the idea of a traditional Polish way of life. They explain why, at least in the analyzed example of the counter-marches, the neo-traditionalist worldview is still so resistant.

13 Beads as described by a participant in the LGBT parade in Lublin. 
To answer the question posed by Jacqueline Rose regarding the uncertainty of any identity, neo-traditionalist fantasies enable subjects to hold on to the contingent neo-traditionalist discourse, notwithstanding the emancipatory impetus of liberalism. By narrating fantasies, the counter-demonstrators provide the neo-traditionalist discourse with an ideological layer that fosters the mobilization against the 'foreign colonial power'.

While the counter-marches are just a part of the entire neo-traditionalist universe, the fundamental fantasy reveals its unity. The sublimated object represents a certain idea of Polishness. Its content is by nature elusive; however, it incarnates the lost wholeness: "In political terms, that is exactly what I have called a hegemonic relation: a certain particularity which assumes the role of an impossible universality" (Laclau, 2005a, p. 115). The purpose of these meaningful objects is to condense the neo-traditionalist idea of Polishness into the cross, the rosary, the Polish flag. It signals the intention of hegemonizing Polish society in a partial element that embodies the 'authentic way of life'. Therefore, apart from the ideational content of the neo-traditionalist discourse, this article identifies an additional level beneath the surface. Fantasies link the substance of the discourse with the level of desire. Thus, the cultural war is not fought only by deploying a political strategy and setting political demands. It also involves the narration of fantasies that promise to achieve again the real Polish way of life. By structuring their 'enjoyment', fantasies grip subjects to their concept of Polishness and, eventually, radicalize the clash.

\section{References}

Benczes, I., Kollai, I., Mach, Z., \& Vigvári, G. (2020). Conceptualisation of neo-traditionalism and neo-feudalism (POPREBEL, Working Paper no. 2).

Biegoń, D. (2016). Hegemonies of legitimation discourse: Dynamics in the European Commission. Palgrave Macmillan. https://doi.org/10.1057/9781137570505

Biglieri, P., \& Perelló, G. (2020). Populism. In Y. Stavrakakis (Ed.), The Routledge handbook of psychoanalytic political theory (pp. 330-340). Routledge. https://doi.org/10.4324 19781315524771

Bill, S. (2020). Counter-elite populism and civil society in Poland: PiS's strategies of elite replacement. East European Politics and Societies: and Cultures, 2020.1-23. https://doi.org $/ 10.1177 / 0888325420950800$

Burke, E. (2003). Reflections on the revolution in France. Yale University Press.

Bustikova, L., \& Guasti, P. (2017). The illiberal turn or swerve in Central Europe? Politics and Governance, 5(4), 166-176. https://doi.org/10.17645/pag.v5i4.1156

Buzogány, A., \& Varga, M. (2018). The ideational foundations of the illiberal backlash in Central and Eastern Europe: The case of Hungary. Review of International Political Economy, 25(6), 811-828. https://doi.org/10.1080/09692290.2018.1543718

Cap, P. (2018). 'We don't want any immigrants or terrorists here': The linguistic manufacturing of xenophobia in the post-2015 Poland. Discourse \& Society, 29(4), 380-398. https://doi.org $/ 10.1177 / 0957926518754416$ 
Carse, A. L. (1994). The liberal individual: A metaphysical or moral embarrassment? Noûs, 28(2), 184-209. https://doi.org/10.2307/2216048

Chlebda, W. (2017). Czy polskość jest (słownikowo) definiowalna? Sprawy Narodowościowe: Seria Nowa, 2017(49), Article 1159. https://doi.org/10.11649/sn.1159

Dąbrowska, E. (2019). New conservatism in Poland: The discourse coalition around Law and Justice. In K. Bluhm \& M. Varga (Eds.), New conservatives in Russia and East Central Europe (pp. 92-112). Routledge. https://doi.org/10.4324/9781351020305-5

Fisher, C. (2005). HRD attitudes: Or the roles and ethical stances of human resource developers. Human Resource Development International, 8(2), 239-255. https://doi.org /10.1080/13678860500100616

Friedman, J. (1988). Cultural logics of the global system: A sketch. Theory, Culture \& Society, 5(2-3), 447-460. https://doi.org/10.1177/0263276488005002014

Friedman, J. (1994). Cultural identity and global process. SAGE.

Galvan, D. (2007). Neotraditionalism. In M. Bevir (Ed.), Encyclopaedia of governance (pp. 599-601). SAGE.

Glynos, J. (2008). Ideological fantasy at work. Journal of Political Ideologies, 13(3), 275-296. https://doi.org/10.1080/13569310802376961

Glynos, J., \& Howarth, D. (2007). Logics of critical explanation in social and political theory. Routledge. https://doi.org/10.4324/9780203934753

Glynos, J., \& Howarth, D. (2008). Critical explanation in social science: A logics approach. Swiss Journal of Sociology, 34(1), 5-35.

Gombrowicz, W. (1994). Trans-Atlantyk (C. French \& N. Karsov, Trans.). Yale University Press. Grabowska, M. (2020). Prawa człowieka w polskiej debacie nad aborcją w perspektywie wojen kulturowych: Studium przypadku. In M. Jaszczewska \& T. Kopac (Eds.), Chrześcijaństwo (pp. 59-72). Wydawnictwo Uniwersytetu Gdańskiego.

Hawkins, B. (2015). Fantasies of subjugation: A discourse theoretical account of British policy on the European Union. Critical Policy Studies, 9(2), 139-157. https://doi.org/10.1080 /19460171.2014.951666

Homer, S. (2020). Lacanian left. In Y. Stavrakakis (Ed.), The Routledge handbook of psychoanalytic political theory (pp. 95-106). Routledge. https://doi.org/10.4324/9781315524771 Ignazi, P. (1992). The silent counter-revolution: Hypotheses on the emergence of extreme right parties in Europe. European Journal for Political Research, 22(1), 3-34. https://doi.org /10.1111/j.1475-6765.1992.tb00303.x

Jowitt, K. (1983). New world disorder: The Leninist extinction. University of California Press. Korolczuk, E., \& Graff, A. (2018). Gender as "Ebola from Brussels": The anticolonial frame and the rise of illiberal populism. Signs: Journal of Women in Culture and Society, 43(4), 797-821. https://doi.org/10.1086/696691

Kotwas, M., \& Kubik, J. (2019). Symbolic thickening of public culture and the rise of rightwing populism in Poland. East European Politics and Societies: and Cultures, 33(2), 435-471. https://doi.org/10.1177/0888325419826691 
Krzyżanowski, M. (2018). Discursive shifts in ethno-nationalist politics: On politicization and mediatization of the "refugee crisis" in Poland. Journal of Immigrant \& Refugee Studies, 16(1-2), 76-96. https://doi.org/10.1080/15562948.2017.1317897

Kubik, J. (2018). FATIGUE and POPREBEL: What are they all about? A programmatic statement: Marie Skłodowska-Curie Actions. Populism Europe. https://populism-europe.com/wp-content /uploads/2019/10/Programmatic-Manifesto-POP-and-FAT-18-October-2019.pdf

Laclau, E. (1990). New reflections on the revolution of our time. Verso.

Laclau, E. (2005a). On populist reason. Verso.

Laclau, E. (2005b). Populism: What's in a name? In F. Panizza (Ed.), Populism and the mirror of democracy (pp. 32-49). Verso.

Laclau, E., \& Mouffe, C. (1985). Hegemony and socialist strategy: Towards a radical democratic politics. Verso.

Melito, F. (2021). Finding the roots of neo-traditionalist populism in Poland: 'Cultural displacement' and European integration. New Perspectives, 29(1), 23-44. https://doi. org/10.1177/2336825X20954756

Orbán, V. (2014). Prime Minister Viktor Orbán's speech at the 25th Bálványos Summer Free University and Student Camp: 26 July 2014, Tusnádfürdó (Băile Tuşnad), Romania. https://2015-2019 .kormany.hu/en/the-prime-minister/the-prime-minister-s-speeches/prime-minister-viktor -orban-s-speech-at-the-25th-balvanyos-summer-free-university-and-student-camp

Porter-Szúcs, B. (2017). The birth of the Polak-Katolik. Sprawy Narodowościowe: Seria Nowa, 2017(49), Article 1280. https://doi.org/10.11649/sn.1280

Rata, E. (2007). The political strategies of ethnic and indigenous elites. In E. Rata, R. Openshaw, \& J. Friedman (Eds.), Public policy and ethnicity: The politics of ethnic boundary-making (pp. 40-53). Palgrave Macmillan. https://doi.org/10.1057/9780230625303_3

Remling, E. (2018). Logics, assumptions and genre chains: A framework for poststructuralist policy analysis. Critical Discourse Studies, 15(1), 1-18. https://doi.org/10.1080/17405904 .2017 .1382382

Rensmann, L. (2017). The noisy counter-revolution: Understanding the cultural conditions and dynamics of populist politics in Europe in the digital age. Politics and Governance, 5(4), 123-135. https://doi.org/10.17645/pag.v5i4.1123

Rose, J. (2005). The Question of Zion. Princeton University Press. https://doi.org/10.1515 $/ 9781400826520$

Sadurski, W. (2018). How democracy dies (in Poland): A case study of anti-constitutional populist backsliding (Sydney Law School Research Paper No. 18/01). SSRN Electronic Journal. https://doi.org/10.2139/ssrn.3103491

Sharpe, M., \& Turner, K. (2020). Fantasy. In Y. Stavrakakis (Ed.), The Routledge handbook of psychoanalytic political theory (pp. 187-198). Routledge. https://doi.org/10.4324/9781315524771

Shils, E. (1958). Tradition and liberty: Antinomy and interdependence. Ethics, 68(3), 153-165. https://doi.org/10.1086/291166

Stavrakakis, Y. (1999). Lacan and the political. Routledge. https://doi.org/10.4324 19780203006160 
Trencsényi, B. (2014). Beyond liminality? The Kulturkampf of the early 2000s in East Central Europe. Boundary 2, 41(1), 135-152. https://doi.org/10.1215/01903659-2409703

Walder, A. G. (1986). Communist neo-traditionalism: Work and authority in Chinese industry. University of California Press.

Yatsyk, A. (2020). Biopolitical populism in Poland: The case of PiS. Populism, 3(2), 148-164. https://doi.org/10.1163/25888072-BJA10015

Zicman de Barros, T. (2020). Desire and collective identities: Decomposing Ernesto Laclau's notion of demand. Constellations, 2020, 1-11. https://doi.org/10.1111/1467-8675.12490

Zielonka, J. (2018). Counter-revolution: Liberal Europe in retreat. Oxford University Press.

Žižek, S. (1989). The sublime object of ideology. Verso.

Žižek, S. (1993). Tarrying with the negative: Kant, Hegel, and the critique of ideology. Duke University Press. https://doi.org/10.2307/j.ctv11hphn6

\title{
Broniąc tradycyjnego polskiego stylu życia. Rola fantazji
}

\begin{abstract}
Abstrakt
Aktualnie zaostrzający się konflikt kulturowy w Polsce określa się mianem wojny kulturowej między światopoglądem neotradycjonalistycznym a liberalnym. Odwołując się do psychoanalitycznej teorii politycznej i poststrukturalistycznej teorii dyskursu, autor uznaje fantazmatyczne narracje za narzędzie maskujące niekonieczny (non-necessary) charakter tożsamości. Na podstawie bezpośredniej obserwacji kontrmanifestacji organizowanych jako sprzeciw wobec marszów równości w Kaliszu, Lublinie i Krakowie (2019-2020) w artykule zaprezentowano, w jaki sposób fantazje definiują „prawdziwy polski styl życia”: poczynając od obrazu tradycyjnej rodziny w sielankowym otoczeniu (beatific fantasy), na "wirusie LGBT" (horrific fantasy) kończąc, fantazje podtrzymują neotradycjonalistyczną koncepcję polskości i wykluczają jej odmienne wizje. Z kolei symbole religijne zinstrumentalizowano tak, by ucieleśniały utraconą jedność - harmonijne społeczeństwo bez konfliktów wywoływanych przez liberalny system wartości. Fantazmatyczna logika analizowana w artykule pozwala wyjaśnić, jak neotradycjonalistyczne fantazje wzmacniają tożsamości i dostarczają niezbędnej podstawy ideologicznej, aby stawić opór emancypacyjnemu naporowi liberalizmu.
\end{abstract}

Słowa kluczowe: neotradycjonalizm; poststrukturalistyczna teoria dyskursu; fantazja; logiki krytycznego wyjaśniania (logics approach); polskość

\section{Citation}

Melito, F. (2021). Defending the traditional Polish way of life: The role of fantasies. Sprawy Narodowościowe: Seria nowa, 2021(53), Article 2546. https://doi.org/10.11649/sn.2546 